building with words

specifications, regulations, contracts

further reading required
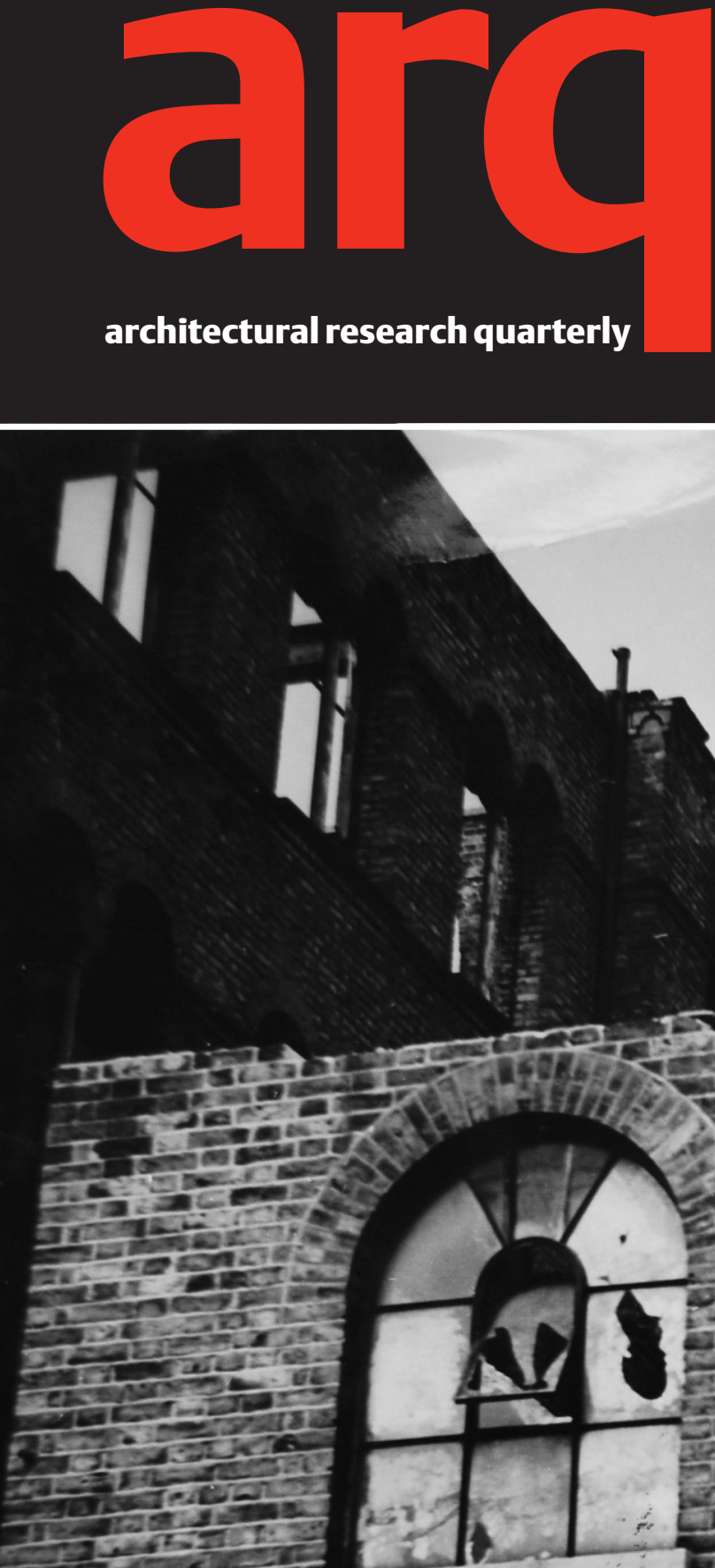

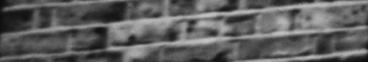

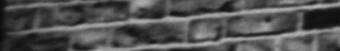
- 2015 -
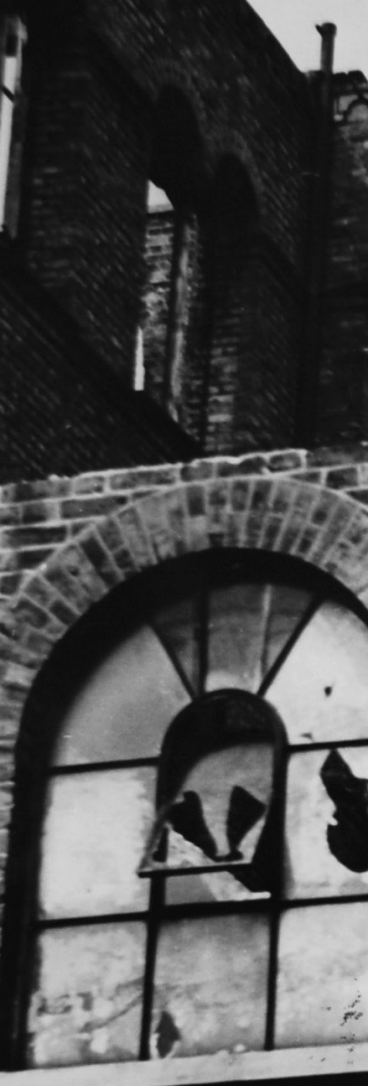
202

3.1.

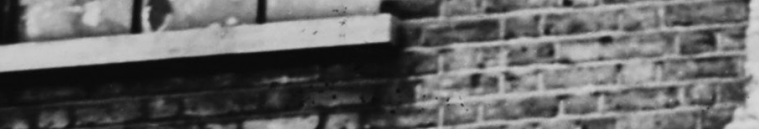

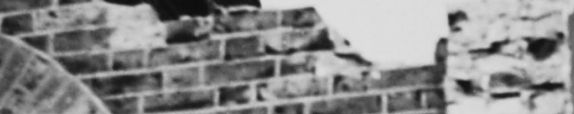

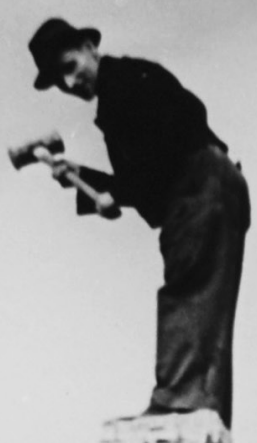

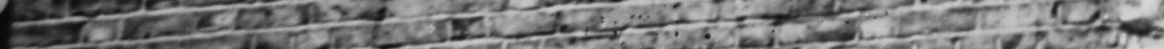
20.

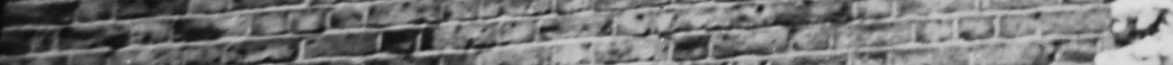

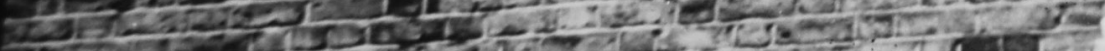
290

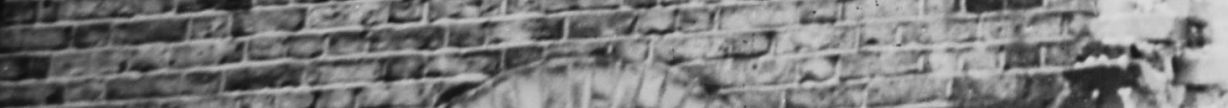

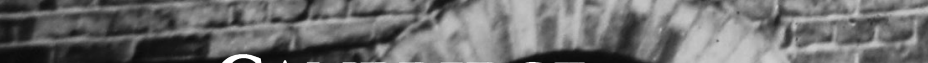

CAMBREGE - TUNIVERSITY PRESS 
Editors-in-Chief RichardWeston

Ewestonr1@cardiff.ac.uk

Adam Sharr

E adam.sharr@newcastle.ac.uk

The Welsh School of Architecture

Cardiff University

Bute Building

King Edward viI Avenue

Cardiff, CF10 3NB, UK

$\mathrm{T}+44(29) 20874431$

$\mathrm{F}+44(29) 20874926$

Editors Julie Gwilliam

E gwilliamja@cardiff.ac.uk

Stephen Kite

E kites@cardiff.ac.uk

Juliet Odgers

E odgersj@cardiff.ac.uk

Associate Editors Samuel Austin

Edward Wainwright

E arq@cardiff.ac.uk

Associate Editor Charles Rattray

Reviews + Insight School of the Environment

University of Dundee

Perth Road

Dundee

DH1 $4 \mathrm{HU}$

M +44(0)7971 197912

$\mathrm{T}+44(0) 1382385231$

Ec.rattray@dundee.ac.uk

Art Editor+Design Angela Ashton

E design@angelaashton.co.uk

Contributing Editors Carlos Eduardo Comas Universidade Federal do Rio Grande do Sul, Brazil

Thomas Fisher University of Minnesota, Minneapolis, USA

Tony Fretton Tony Fretton Architects, London, UK

Elizabeth Hatz KTH Arkitekturskolan, Stockholm, Sweden

Susanne Hofmann Die Baupiloten, TU Berlin, Germany

Louisa Hutton Sauerbruch Hutton Architects, Berlin, Germany

Mari Hvattum Oslo School of Architecture and Design, Norway

Momoyo Kaijima Atelier Bow-Wow, Tokyo, Japan

David Leatherbarrow University of Pennsylvania, Philadelphia, USA

Hannah Le Roux University of the Witwatersrand, Johannesburg, South Africa

Tarla MacGabhann MacGabhann Architects, Letterkenny, Republic of Ireland

Mary McLeod University of Columbia, New York, USA

Michael Ostwald The University of Newcastle, Australia

Simo Paavilainen Helsinki University of Technology, Finland

Alan Powers University of Greenwich, London, UK

Mohamed Sharif Koning Eizenberg Architecture, Santa Monica, CA, USA

Editorial Board Simon Allford Allford Hall Monaghan Morris, London, UK

Andrew Ballantyne University of Newcastle, UK

Peter Blundell Jones University of Sheffield, UK

Peter Carolin University of Cambridge, UK

Richard Coyne University of Edinburgh, UK

Wayne Forster Cardiff University, UK

Brian Ford University of Nottingham, UK

David Jenkins Foster and Partners, London, UK

Niall McLaughlin Niall McLaughlin Architects, London, UK

Jane Rendell Bartlett School of Architecture, UCL, London, UK

Jonathan Sergison Sergison Bates Architects, London, UK

Koen Steemers University of Cambridge, UK

Robert Tavernor London School of Economics, UK

Jane Wernick Jane Wernick Associates, London, UK

lain Boyd Whyte University of Edinburgh, UK

arq: Architectural Research Quarterly (issn 1359-1355) is published four times a year in March, June, September and December. Four parts form a volume. The subscription price which includes print and electronic access (but excluding vat) of volume 16 is $£ 220.00$ (US \$370.00 in USA, Canada and Mexico) for institutions; $£ 44.00$

(US $\$ 68.00$ in USA, Canada and Mexico) for individuals and $\mathrm{E}_{32.00}$ (US $\$ 55.00$ in USA,

Canada and Mexico) for students, which includes print only, ordering direct from the publishers and certifying that the journal is for their personal use. Single parts are $£ 56.00$ net (US \$90.00 in USA, Canada and Mexico) plus postage. EU subscribers (outside the UK) who are not registered for vat should add vat at their country's rate. vat registered members should provide their vat registration number. Japanese prices for institutions (including ASP delivery) are available from Kinokuniya Company Ltd, P.O. Box 55, Chitose, Tokyo 156, Japan. Orders which must be accompanied by payment, may be sent to a bookseller, subscription agent or direct to the publisher: Cambridge University Press,

The Edinburgh Building, Shaftesbury Road, Cambridge CB2 8RU; or in the USA, Canada and

Mexico: Cambridge University Press, Journals Fulfillment Department, 100 Brook Hill Drive, West Nyack, NY 10994-2133. Copies of the journal for subscribers in the USA, Canada and Mexico are sent by air to New York to arrive with minimum delay.

Copying

The journal is registered with the Copyright Clearance Center, 222 Rosewood Drive, Danvers, MA 01923, USA. Organizations in the USA who are also registered with C.C.C may therefore copy material (beyond the limits permitted by sections 107 and 108 of U.S. Copyright law) subject to payment to C.C.C. of the per-copy fee of \$16. This consent does not extend to multiple copying for promotional or commercial purposes. Code 1359-1355/2012/\$16.

ISI Tear Sheet Service, 3501 Market Street, Philadelphia, PA 19104, USA, is authorized to supply single copies of separate articles for private use only.

Organizations authorized by the Copyrigh Licensing Agency may also copy material subject to the usual conditions.

For all other use, permission should be sough from Cambridge or from the American Branch of Cambridge University Press.

Information on arq: Architectural Research Quarterly and all other Cambridge journals can be accessed via http://www.journals.cambridge.org/

This journal issue has been printed on FSC-certified paper and cover board. FSC is an independent, non-governmental, not-for-profit organization established to promote the responsible management of the world's forests. Please see www.fsc.org for information.

(c) Cambridge University Press 2012 
COVER

'Clearing the way

for the Exhibition'

(1948). London

Metropolitan

Archives,

Photographic

Collection.

Seepp 245-252 leader
report
perspective

design

criticism

theory

history

practice

sight

subscribe

\section{Building with words}

197 Further Reading Required Tilo Amhoff, Nicholas Beech and Katie Lloyd Thomas reflect on the event they organised at the Bartlett, $\mathrm{UCL}$

200 Regulating architecture Mark Dorrian situates the Further Reading Required conference in a broader context

205 On contradictory regulations Liam Ross tests Scottish regulations for window cleaning against the contradictory conservation rules for Edinburgh New Town

210 'WLTM caring contractor': the dating game of Design and Build contracts Sarah Wigglesworth contrasts the contractual relationships involved in two building projects

218 Specifying intent at the Museum of Childhood Mhairi McVicar considers definitions of ambiguity, quality and precision as they apply to the pursuit of architectural quality in Caruso St John Architects' 2006 entrance addition

229 'Of their several kinds': forms of clause in the architectural specification Drawing on the work of Gilbert Simondon, Katie Lloyd Thomas explores the significance of changes in the way that clauses specify materials and constructions

238 'Except where herein otherwise directed': building with legal documents in early nineteenth century England Reading legal documents of Georgian architects, Tilo Amhoff examines the emergence of the codified structures and professional relations of building

245 Demolition figures: the appearance and expression of the topman and mattockman in LCC contracts, 1941-1951 Nicholas Beech traces how changes in the form of demolition contract mark a transition from skilled to mechanised labour

253 Integrated. Dis-integrated. Coordinated. Re-integrated Beginning in ancient Greece, John Gelder charts the fragmentation of contract documentation through the Renaissance and looks forward to re-integration through BIM

261 What is a building? Documents for the contractual diagramming of design Anne Bottomley and Nathan Moore examine two case studies in the relationship between the design of contract forms and the design of buildings

269 Sub-Plan: A Guide to Permitted Development The UK's rules on what may be built without planning approval are confusing. David Knight and Finn Williams show how applying them can produce alarming - and amusing - results

A subscription form, which may be photocopied, can be found on page 196 of this issue 


\section{TABLE OF CONTENTS.}

Editorial Announcements :

To Readers - Literary ContributionsIllustrations - To Correspondents

Introduction :

Points to ensure a well-written Specification-Note for Subscribers

DIVISI0N I. Construction.

\section{General Conditions:}

General Notes-Specification Clauses -The London Building Act $\mathrm{I}_{3}-17$

Excavator:

General Notes-Foundations-Piles - Specification Clauses-The London Building Act-Glossary $\quad \mathrm{t}_{9}-23$

Well=Sinker :

Shallow Wells-Deep Wells-Glos-

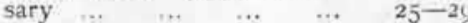

icretor:

General Notes-Materials-Application to various Positions-Specification Clauses - The London Building Act-Glossary ... $31-35$

Bricklayer :

Bricks-Details and Purposes-Piers - Furnace Chimney Shafts - Workmanship-Specification ClausesThe London Building Act-Glossary

Drainlayer:

House Drainage-Town or District Sewerage-Specification ClausesThe London Building Act-Glossary

Terra Cotta Worker:

Designing - Materials - Manufacturing No:e;-Building-Specification Clauses - The London Building Act-Glossary $\quad \ldots \quad \ldots \quad 55-\tilde{5}^{\prime}$

Mason :

eneral Notes - Selection - Setting Masonry-Specification ClausesThe London Building Act-Glos-

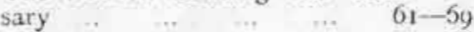

Pavior:

Plain Paving-Decorated PavingSpecification Clause 3-The London Building Act-Glossary ... $\quad 71-73$

Carpenter:

General Notes-Floors-GirdersRoofs - Partitions, Linings, and Fencing-Half Timber WorkSelection and Detection-Spectator's Stands-Specification Clauses' -The London Building ActGlossary

Joiner :

Materials - Floors - D oors-Windowz -Specification Clauses-The London Building Act-Glossary $\quad 89-99$

Ironmonger :

Doors-Door Checks-WindowsSpecification Clause;-The London Building Act-Glossiry $\quad \ldots \quad 10 \mathrm{I}-10_{5}$

Slater:

Slate Rock:-Roofing - Specification Clauses - The London Building Act, -Glossary roj-JII
Tiler:

Roofing Tiles-Tables-Miscellaneous Roofings - Specification ClausesThe London Building Act-Glossary

Thatcher:

General Notes-Materials-Workmanship-Specification Clauses The London Building Act-Glossary

Structural Engineer:

General Notes--Structural CastingsWrought Iron - Steel - Iron and Steel Sheets-All-iron Roofing Cast Iron Columns and Stanchions - Iron and Steel Joists or Girders Compound Joists or Girders Painting Iron and Steel Work-Specification Clauses - The London Building Act - Glossary ... 123-14!

Fireproof Construction :

General Notes-Materials-Fireproof Construction-Specification Clauses -The London Building Act $\quad 143-14 y$

\section{Heating Engineer:}

General Notes-Systems--Specification Clzuses - The London Building Act $\ldots \ldots{ }_{5}{ }^{1-1}-155$

Horticultural Engineer:

Conservatories - Glasshouses for Special Purposes - Miscellaneous Houses: Heating, Cooling, and Ventibting-The London Building Act-Glossary _... … $157-161$

Hydraulic Engineer:

Power-Pumps and Engines - LiftsSpecification Clauses-The London Building Act-Glossary ... ${ }^{16} 63-167$

Mechanical Engineer:

Ganeral Notes-Buildings - Foundations - Boilers - Specification Clause: - The London Building Act-Glossary $\quad \ldots . \quad \ldots \quad 160-175$

Ventilating Engineer:

General Notes-Natural Ventilation - Specification Clauses - The London Building Act-Glossary $\quad 177-18$

Founder :

General Notes-Light Constructional Cast-iron Work - Grates, Chimney Pieces, Stoves, etc--Specification Clauses - The London Building Act-Glossary … $\quad 183-187$

\section{Smith :}

General Notes - Small Structural Smithery-Specification ClausesThe London Building Act-Glossary ... ... ... $\quad 189-193$

Art Metal Worker:

Ornamental Ironwork-Ornamental Copper-Specification Clauses $195-197$

Zincworker and Coppersmith:

Zincworker-Coppersmith-Specificatiun Clauses-The London Building $\begin{array}{llll}\text { Act -Glossary } \quad \ldots & 199 & 203\end{array}$

Electrician :

Lighting-Specification Clauses The London Building Act - Glossary 205-213

Bellhanger:

Mechanical Bells - Pneumatic BellsElectric Bulls-Specification Clauses -The Londion Building ActGlossary
Gasfitter :

Illumination - Service-Specification Clauses - The London Building Act-Glossary $\quad \ldots \quad \ldots \quad 22 \mathrm{t}-22,5$

Plumber:

General Notes-External PlumberSpecification Clauses - The London Building Act-Glossary ... 227-235

Plasterer :

Limes-Cements-Plasters-Internal Work-External Work-Specification Clauses-The London Building $\begin{array}{llll}\text { Act-Glossary } & \ldots & \ldots & 237-243\end{array}$

Glazier:

Glass-Glazing with Putty - Specification Clauses-The London Building $\begin{array}{llll}\text { Act-Glossary } \quad \ldots & \ldots & 245-249\end{array}$

Painter and Decorator:

General Notes-Painting-Varnishing - Gilding - Distempering Specification Clauses - The London Building Act-Glossary … 25t-257

\section{Paperhanger :}

General Notes-Old Work-Specifi. cation Clauses-The London Building Act-Glossary ... ... $\quad 259-263$

Blind Maker:

Inside Blinds - Outside Blinds Specification Clauses-Glossary

Furnisher :

Private Building - Public Buildings The London Building Act-Glossary

Gardener :

Entrance Gates, Lodge, and Approach - Garden Plan-Flower GardenSpecification Clauses-Glossary

Road Maker:

Roads and Streets - Footpaths Specituation Clauses-The London Building Act-Glossary ... $28 \mathrm{r}-285$

DIVISION II. Proiessional Practice.

Surveyor:

Dilapidations-Ancient Lights-Mensuration Rules-Tables-Scales of Fees-Glossary $289-295$

Hygienic Engineer:

Water Supply - Sewrerage - Specification Clauses - The London Building Act-Glossary _... _... 297-303

Legal :

Some leading Principles of the Law of Contracts in England and IrelandAnnouncements ... … 305-307

Miscellaneous :

Customs

DIVISION III.

\section{Buildings in Progress.}

The Surveyors' Institution ... 312 Colchester Town Hall North Bridge Street, Edinburgh $\quad \ldots \quad 314$ Belfast City Hall 315 Paddockhurst, Sussex The Guildhall, Cambridge _ _... 317 Town Hall and Law Courts, Cardiff 318,319 House for Mr. Julian Sturgis _. $\quad 320$

For Advertisers' Directory see Page 8. 